\title{
Hangtani és alaktani vizsgálatok Medvesalja magyar nyelvjárási atlasza alapján*
}

1. Bevezetés. A medvesalji falvak az egykori Gömör megyének Nógráddal határos délnyugati részén - a mai Szlovákia területén - a Gortva-patak völgyében fekszenek.

Eredetileg Gömöralmágy, Medveshidegkút, Óbást, Gömörpéterfala, Tajti és Vecseklő településeket szokás medvesalji falvaknak nevezni (vö. BENKÖ ÉvA, Nagycsalád a Medvesalján. Kossuth Lajos Tudományegyetem Néprajzi Tanszék, Debrecen, 1986. 13). A környékbeliek az előbbi falvaktól északra fekvő Ajnácskőt tartják a választónak. Tőle déli irányban az egész területre érvényes ma már a „,medvesalji” jelző, hiszen a gazdaságitársadalmi-kulturális kapcsolatok szorosabbá váltak. A falvak lakói átjárnak egymáshoz dolgozni, mulatni, s gyakori a szomszéd faluból való házasodás is.

Medvesalja lakossága római katolikus vallású, kultúrájában, népszokásaiban, nyelvjárásában erősen hagyományőrző, nem egy tekintetben archaikus.

A tizenkét települést (1. Söreg, 2. Ajnácskő, 3. Csevice, 4. Gömöralmágy, 5. Dobfenek, 6. Gömörpéterfala, 7. Óbást, 8. Egyházasbást [Újbást], 9. Bakóháza, 10. Vecseklö, 11. Medveshidegkút, 12. Tajti [1. melléklet: MedvA. ${ }^{1}:$ A kutatópontok térképe]) magában foglaló tájegység mai lakosságának döntő többsége mezőgazdasági munkából igyekszik megélni, de egyre többen járnak be a közeli városokba, Fülekre, Rimaszombatba dolgozni. A fiatalok pedig, mihelyt tehetik, elhagyják falujukat.

Az utóbbi három évtized népszámlálási adatait alább bemutató táblázat ${ }^{2}$ részletes elemzést kívánna, most azonban témánk szempontjából csak a legfontosabb tendenciára, a magyar lakosság lélekszámának a rohamos csökkenésére irányíthatom a figyelmet.

\section{1. táblázat}

Medvesalja településeinek népszámlálási adatai

\begin{tabular}{|l|l|l|l|l|l|l|l|}
\hline \multicolumn{1}{|c|}{ Település } & összlakosság & magyar & \% & szlovák & \multicolumn{1}{c|}{$\%$} & roma & \% \\
\hline \multirow{4}{*}{ 1. Sőreg } & $1991: 602$ & 558 & 92,69 & 44 & 7,30 & & \\
& $2001: 538$ & 483 & 89,77 & 53 & 9,85 & & \\
& $2011: 481$ & 390 & 81,08 & 62 & 12,89 & & \\
\hline \multirow{3}{*}{ 2. Ajnácskő } & $1991: 1200$ & 1075 & 89,58 & 118 & 9,83 & & \\
& $2001: 1164$ & 1004 & 86,25 & 146 & 12,54 & & \\
& $2011: 1193$ & 972 & 81,48 & 183 & 15,34 & & \\
\hline 3. Csevice & & & & & & & \\
\hline \multirow{3}{*}{ 4. Gömöralmágy } & $1991: 712$ & 674 & 94,66 & 31 & 4,35 & 0 & 0 \\
& $2001: 701$ & 629 & 89,73 & 61 & 8,70 & 6 & 0,86 \\
& $2011: 693$ & 536 & 77,34 & 77 & 11,11 & 54 & 7,79 \\
\hline
\end{tabular}

*A Magyar Nyelvtudományi Társaság 2013. május 8-i felolvasóülésén elhangzott előadás szerkesztett változata.

${ }^{1}$ MedvA. = Cs. Nagy Lajos, Medvesalja magyar nyelvjárási atlasza. Luminosus n. o. Kiadó, Nagykapos. 2011.

${ }^{2}$ A táblázat a http://varaljaszovetseg.hu/felvidek2011.pdf (2013.06. 10.) adatainak a fölhasználásával készült.

${ }^{3}$ Csevice közigazgatásilag Ajnácskőhöz tartozik. Az adat forrása: Štatisticky lexikon obci ČSSR 1982. SEVT, Praha, 1984. 2: 1236-1237. 


\begin{tabular}{|c|c|c|c|c|c|c|c|}
\hline 5. Dobfenek & $\begin{array}{l}\text { 1991: } 171 \\
\text { 2001: } 138 \\
\text { 2011: } 153\end{array}$ & $\begin{array}{l}164 \\
134 \\
135 \\
\end{array}$ & $\begin{array}{l}95,91 \\
97,10 \\
88,24 \\
\end{array}$ & $\begin{array}{l}4 \\
4 \\
13 \\
\end{array}$ & $\begin{array}{l}2,34 \\
2.90 \\
8,50 \\
\end{array}$ & & \\
\hline 6. Gömörpéterfala & $\begin{array}{l}\text { 1991: } 311 \\
\text { 2001: } 268 \\
\text { 2011: } 250\end{array}$ & $\begin{array}{l}298 \\
258 \\
215 \\
\end{array}$ & $\begin{array}{l}95,82 \\
96,27 \\
86,00 \\
\end{array}$ & $\begin{array}{l}8 \\
10 \\
16 \\
\end{array}$ & $\begin{array}{l}2,57 \\
3,73 \\
6,40 \\
\end{array}$ & & \\
\hline 7. Óbást & $\begin{array}{l}\text { 1991: } 417 \\
\text { 2001: } 378 \\
\text { 2011: } 326\end{array}$ & $\begin{array}{l}408 \\
356 \\
288\end{array}$ & $\begin{array}{l}97,84 \\
94,18 \\
88,34\end{array}$ & $\begin{array}{l}7 \\
21 \\
29\end{array}$ & $\begin{array}{l}1,68 \\
5,56 \\
8,90\end{array}$ & & \\
\hline 8. Egyházasbást & $\begin{array}{l}\text { 1991: } 578 \\
\text { 2001: } 546 \\
\text { 2011: } 537\end{array}$ & $\begin{array}{l}533 \\
493 \\
402 \\
\end{array}$ & $\begin{array}{l}92,21 \\
90,29 \\
74,86 \\
\end{array}$ & $\begin{array}{l}26 \\
28 \\
65 \\
\end{array}$ & $\begin{array}{l}4,50 \\
5,13 \\
12,10 \\
\end{array}$ & $\begin{array}{l}6 \\
22 \\
41 \\
\end{array}$ & $\begin{array}{l}1,04 \\
4,03 \\
7,64 \\
\end{array}$ \\
\hline 9. Bakóháza ${ }^{4}$ & & & & & & & \\
\hline 10. Vecseklö & $\begin{array}{l}\text { 1991: } 361 \\
\text { 2001: } 298 \\
\text { 2011: } 256\end{array}$ & $\begin{array}{l}353 \\
285 \\
228 \\
\end{array}$ & $\begin{array}{l}97,78 \\
95,64 \\
89,06 \\
\end{array}$ & $\begin{array}{l}8 \\
11 \\
20 \\
\end{array}$ & $\begin{array}{l}2,22 \\
3,69 \\
7,81 \\
\end{array}$ & & \\
\hline 11. Medveshidegkút & $\begin{array}{l}\text { 1991: } 291 \\
\text { 2001: } 275 \\
\text { 2011: } 281 \\
\end{array}$ & $\begin{array}{l}270 \\
231 \\
227 \\
\end{array}$ & $\begin{array}{l}92,78 \\
84,00 \\
80,78 \\
\end{array}$ & $\begin{array}{l}17 \\
22 \\
37 \\
\end{array}$ & $\begin{array}{l}5,84 \\
8,00 \\
13,17 \\
\end{array}$ & $\begin{array}{l}4 \\
21 \\
12 \\
\end{array}$ & $\begin{array}{l}1,37 \\
7,64 \\
4,27 \\
\end{array}$ \\
\hline 12. Tajti & $\begin{array}{l}\text { 1991: } 618 \\
2001: 565 \\
2011: 524\end{array}$ & $\begin{array}{l}613 \\
543 \\
494 \\
\end{array}$ & $\begin{array}{l}99,19 \\
96,11 \\
94,27\end{array}$ & $\begin{array}{l}2 \\
13 \\
9 \\
\end{array}$ & $\begin{array}{l}0,32 \\
2,30 \\
1,72\end{array}$ & & \\
\hline
\end{tabular}

Tanulságos összevetni az egyes települések népességének az alakulását. Most a magyar lakosság számbeli változásával foglalkozunk. Legnagyobb mértékben, 17-18\%kal csökkent a magyarok lélekszáma Gömöralmágyban és Egyházasbástban, valamint Medveshidegkúton (12\%-kal). Legkisebb a csökkenés Tajtiban, ahol az 5\%-ot sem éri el. A többi faluban átlagosan 8-10\%-os a veszteség.

A fenti részletező táblázat alapján készült diagramokkal összesítve mutatom be a régió lélekszámának a változását.

\section{2. táblázat}

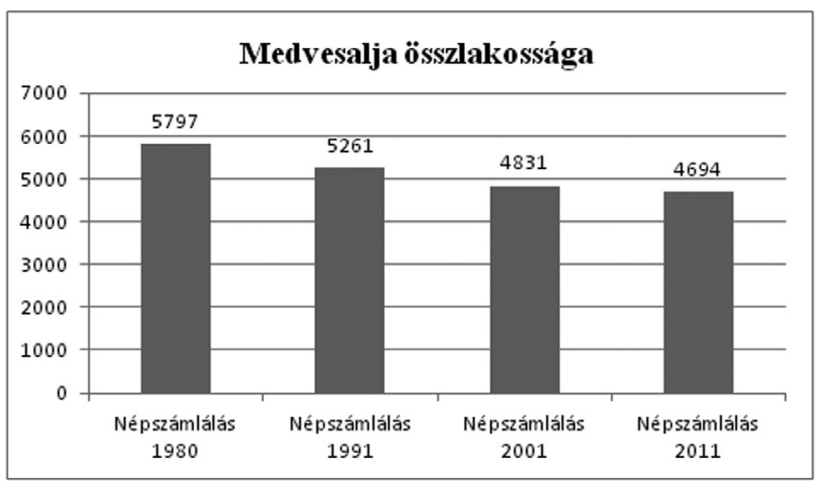

${ }^{4}$ Bakóháza közigazgatásilag Újbásthoz tartozik. Az adat forrása: Štatisticky lexikon obci ČSSR 1982. SEVT, Praha, 1984. 2: 1242-1243. 
Harminc év alatt 1103 fővel, megközelítőleg 1/5-ével, 19,03\%-kal lett kevesebb vizsgált területünk lakossága.

3. táblázat

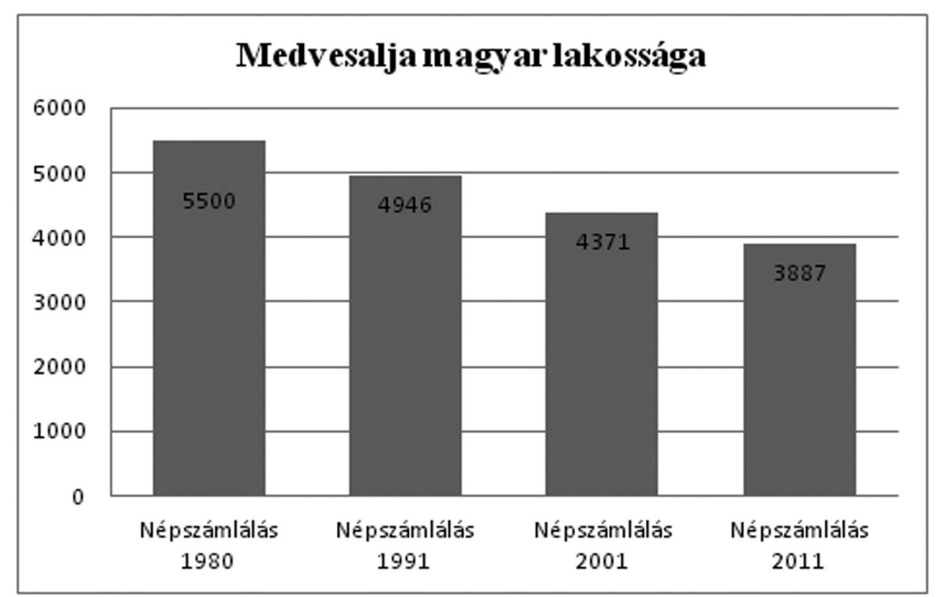

A magyarok lélekszámának változása 3 évtized alatt (1980-tól): -1613 fő (-29,33\%).

\section{4. táblázat}

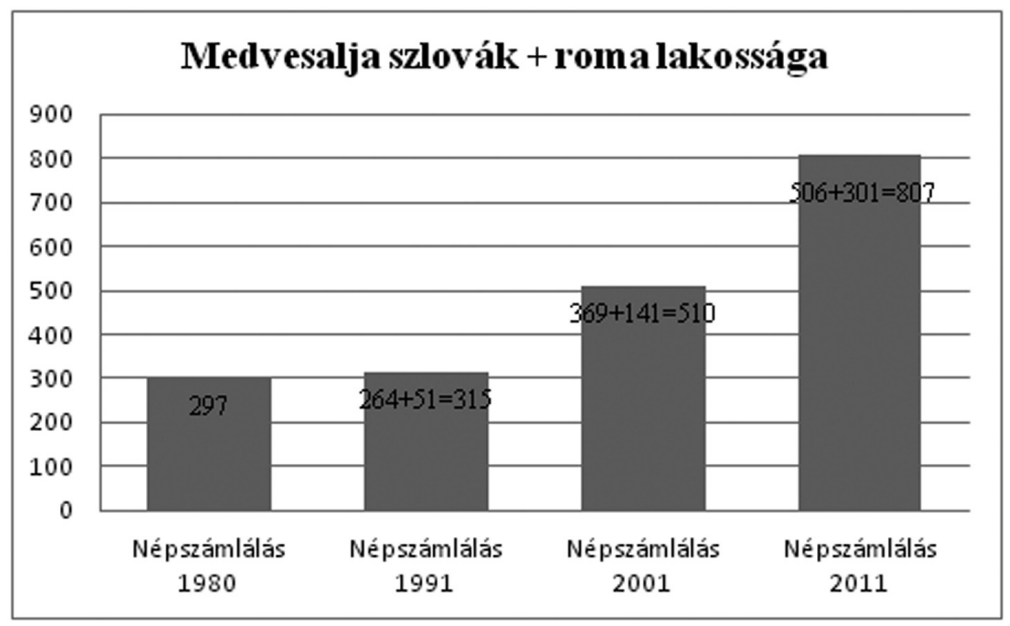

Az 1980-as népszámlálási statisztikák nem tüntetik föl külön-külön a szlovák és az egyéb nemzetiségek lélekszámát, ezért csak az 1991. évivel vethetjük össze a szlovák lakosság mennyiségi változását, mely két évtized alatt $+242(+91,67 \%)$.

A táblázatból kiderül, hogy ezen a tájegységen a 80-as évtizedben valamelyest csökkent vagy stagnált a szlovákság lélekszáma, de 1991-től már egyre eröteljesebb a növekedésük mértéke: az ezredfordulóig +105 fö (+39,78\%), utána pedig újabb +137 fö (+37,13\%).

Funkcionális nyelvjárásvesztést - egyben nyelvvesztést is - eredményez Medvesalján egyrészt a magyar anyanyelvü lakosság fogyása (az idősek elhalálozása és a fiatalok 
elköltözése), másrészt a kisebbségi lét a maga összes negatív következményével. A határ menti helyzet ugyan nyelvileg viszonylag kedvező lenne (kishatárforgalom, Salgótarján közelsége, magyar rádió, televízió, sajtó hatása stb.), de az utódállam ilyen helyeken alapiskolákat is nehezen, középiskolákat, felsőoktatási intézményeket pedig egyáltalán nem hoz létre, s a munkahelyteremtés sem kimondott érdeke. A tanulni, dolgozni, egyáltalán a megélni akaróknak nincs sok választási lehetőségük: kénytelenek elhagyni szülőfalujukat, s kisebb-nagyobb városokban (Rimaszombat, Fülek, Kassa, sőt Pozsony), illetve - nem ritkán - az anyaországban telepednek le.

Mivel a kutatás elsősorban a nyelvjárási alaprétegre irányult, ezért az idősebb korosztályból, a 60 éven felüliekből választottuk adatközlőinket. Ezek a nemzedékek - különösen a 71 év fölöttiek - lehettek volna az 1950 és 1960 között gyüjtött MNyA. adatközlöi is, ha történetesen Medvesaljára is kiterjedt volna az atlaszgyüjtés. Közülük 65-töl kérdeztük ki a nagyatlasz lexikai és morfológiai kérdéseit. Ezáltal megközelítőleg 80000 adathoz jutottunk (78 260). Medvesaljától nem messze azonban északra is, délre is vannak kutatópontok (Cssz-17: Bolyk, Cssz-18: Magyarhegymeg, Cssz-19: Zsip; H-6: Karancslapujtö, H-7: Bárna, H-10: Borsodszentgyörgy), s az innen származó adatok szolgálhatnak a jelen hangtani és alaktani vizsgálat alapjául.

A kutatás empirikus jellegü. Erről a tájegységről kevés nyelvi adatunk van, s ebből következően általában szerényebbek, nyelvi szintenként különbözőek a nyelvhasználati ismereteink is. Bár a hangtan, az alaktan és a szókincstan területéről akadnak elszórtan régi (pl. BoROVSZKY é. n.: 199-203; a nyelvészeti pályázatokban: Csüry-verseny, a Magyar Nyelvőr, a Magyar Nyelv, a Magyar Népnyelv, a Magyar Nyelvjárások, a Nyelvészeti Füzetek köteteiben) adatok, de ezek kevésbé rendszerszerüek (vö. KÁZMÉR 1973: 207-223). Újabban CSÍKÁNY ANDREA doktori dolgozatában foglalkozott a palóc nyelvjárásterület hat településének a szókincsével, valamint hangtani és alaktani állapot- és változásvizsgálatával. Az Új magyar nyelvatlasz anyagának a gyüjtésébe bekapcsolódva a nagyatlasz kutatópontjait kereste föl: egy keleti, négy középpalóc és egy nyugati palóc település anyagát gyüjtötte össze és dolgozta fel (CsíKÁNY 2012).

E tájegység beszélöközösségének nyelvi variabilitását a palóc nyelvjárási jelenségeken belül is kevéssé ismerjük, ezért nélkülözhetetlennek tartom - legalább a kérdőíves gyüjtés alapján - azok bemutatását.

A vizsgálat kiindulási pontjának IMRE SAMU nyelvjárási monográfiáját tekintem, hiszen a nagyatlasz adatai alapján ő fogalmazta meg mind a mai napig legárnyaltabban az egyes nyelvjárástípusok - köztük a középpalóc, ahova Medvesalja is tartozik - legfőbb sajátosságait (vö. IMRE 1971: 349-351).

A következőkben a hangtan és az alaktan területéről mutatom be azokat a legfontosabb nyelvjárási jelenségeket, amelyek egyrészt az ezredforduló táján már kevésbé jellemzőek, mint az atlaszgyüjtés korában voltak, másrészt pedig azokat, amelyek ma is élö elemei a medvesalji nyelvhasználatnak.

Adatközlőim - mint a korábbi táblázatokból kiderült - életkori és iskolázottságbeli különbségei nem számot tevőek - lakhelyük is viszonylag zárt körzetben van - csupán nemük szerint térnek el egymástól. Nyelvhasználati szempontból releváns különbség nem mutatkozik a nemek között. Éppen ezért olyan jellegü többdimenziós változásvizsgálatra anyagom alapján kevésbé nyílik lehetőség, amilyet P. LAKATOS ILONA és T. KÁROLYI MARGIT végzett a hármas határ mentén (P. LAKATOS szerk. 2012). 


\section{Gyengülő nyelvjárási jelenségek}

\subsection{Hangtan}

2.1.1. Az ly fonéma a középpalóc nyelvjárásban eléggé stabilnak mutatkozik (vö. IMRE 1971: 350). Mintha megbomlani, fellazulni látszana ma már ez az állandóság. Elmozdulás tapasztalható az l' és a $j$ irányába: konkoly, konkol', konkoj; pulyka $(2-4,6,9$, 11, 12), pul'kà $(1,4,10)$, pulkà $(7,12)$, pujkà $(1,8)$. [2. melléklet: MedvA. 360. ${ }^{5}$ ] Erröl a kérdésről bővebben 1. Cs. NAGY 1995: 203-209.

\section{5. táblázat}

Az ly fonéma a középpalóc nyelvjárásban

\begin{tabular}{|l|l|l|l|l|l|l|l|l|}
\hline \multirow{2}{*}{ Címszó } & \multicolumn{5}{|c|}{ MNyA. } & \multicolumn{5}{c|}{ MedvA. } \\
\cline { 2 - 10 } & $l y$ & $l, l$ & $j$ & összes & $l y$ & $l, l$ & $j$ & összes \\
\hline konkoly & 6 & 2 & 3 & 11 & 8 & 5 & 2 & 15 \\
\hline pehely & 3 & - & 1 & 4 & 5 & 5 & 1 & 11 \\
\hline pulyka & 4 & - & 1 & 5 & 7 & 5 & 2 & 14 \\
\hline polyva & 6 & - & 4 & 10 & 7 & 6 & 2 & 15 \\
\hline \multirow{2}{*}{ összes } & 19 & 2 & 9 & 30 & 27 & 21 & 7 & 55 \\
& $63,33 \%$ & $6,67 \%$ & $30 \%$ & $100 \%$ & $49,09 \%$ & $38,18 \%$ & $12,72 \%$ & $100 \%$ \\
\hline
\end{tabular}

Tehát az ly megterheltsége gyengült, több mint 10\%-ot csökkent a számuk. Megjegyzendő, hogy a nagyatlasz néhány kutatópontjáról nincs adat. A medvesalji $l, l$ '-es adatok száma jól mutatja a közbülső állapotot.

2.1.2. Általános jelenség az $i$ előtti $t \sim t y, d \sim g y, n \sim n y, l \sim l y$ szembenállás, bár területünkön a nagyatlasz adataihoz képest elmozdulás történt a depalatális irányba. A dinnye esetében például a H-10, Cssz-17, 18. pontokon a $d$-s változat ,újabb alak” minősítést kapott az általános $g y$-vel szemben. Gyüjtésem idején Medvesalján már hozzávetőleg felefele arányban él a két realizáció egymás mellett: dinnye $(2,3,5,7,8,10,12)$, gyinnye $(1$, $4,6,9,11,12)$. (MedvA. 34.) Hasonló képet mutat a dijó gyijó is. Lényegesen kevesebb adatban mutatható ki a palatalizáció a $t$ (öblíti $\sim \ddot{o b l i t y i)}$ és az l (ribizli $\sim$ ribizl'i $\sim$ ribizlyi; csuklik csukl'ik) esetében.

\section{6. táblázat}

Palatalizált alakok a középpalóc nyelvjárásban

\begin{tabular}{|l|l|l|l|l|l|l|}
\hline \multirow{2}{*}{ Címszó } & \multicolumn{3}{|c|}{ MNyA. } & \multicolumn{3}{c|}{ MedvA. } \\
\cline { 2 - 7 } & palatalizált & köznyelvi & összes & palatalizált & köznyelvi & összes \\
\hline dinnye & 5 & 5 & 10 & 6 & 8 & 14 \\
\hline dió & 8 & 7 & 15 & 6 & 9 & 15 \\
\hline öblögeti & 3 & - & 3 & 12 & 4 & 16 \\
\hline szereti* & 6 & 2 & 8 & 9 & 6 & 15 \\
\hline ribizli & 6 & 6 & 12 & 2 & 11 & 13 \\
\hline csuklik & 4 & 4 & 8 & 2 & 11 & 13 \\
\hline \multirow{2}{*}{ összes } & 32 & 24 & 56 & 37 & 49 & 86 \\
& $57,14 \%$ & $42,86 \%$ & $100 \%$ & $43,02 \%$ & $56,98 \%$ & $100 \%$ \\
\hline
\end{tabular}

"Nincs a MedvA.-ban.

${ }^{5}$ A színes atlaszlapokat technikai okokból csak a honlapunkon tudjuk közölni. 
A számszerü adatok e jelenség gyengülését bizonyítják.

2.1.3. Még élő, de a korábbihoz képest már csökkenő mértékü jelenség a meg igekötő $g$-jének hasonulása az ige szókezdő mássalhangzójához. A megnö [3. melléklet: MedvA. 614.] a következő realizációkat mutatja: mëgnő, mëgnyö, mëgnyö mëgnöl (1-3, 5-10) mënnyö, mёnnyö̈, mënyö, mënnö (2-4, 7, 9-12). Hasonlóképpen jelentkezik a mëkfakad mëffàkàd; mënnézzük, mëvver, mëhhi esetében is.

IMRE SAMU azon feltételezése, hogy ,a hasonulás bizonyos fokig függ az indukáló msh.-tól is" (IMRE 1971: 264), adataim alapján nem igazolható. Inkább arról van szó, hogy a palóc nyelvjárás erősebben hajlamos a hangellentétek teljes hasonulással való feloldására, mint más nyelvjárások, illetve a köznyelv. DEME LÁSZLÓ megállapításával érthetünk egyet: ,a hasonulás, ha bekövetkezik, általános, a hang minőségétől független” (DEME 1956: 265). Ez azt is jelenti, hogy a meg igekötő $g$ hangja elvileg - és gyakorlatilag is minden mássalhangzóhoz hasonulhat. Ha föllapozzuk az ÚMTsz. meg igekötős szavait a megabajgat-tól a megzsurmol-ig, akkor szép számmal találunk hasonulásos változatokat: mëbbàgzott (Óbást) '<étel> megsavanyodik', mëccondollyik (Mezőkövesd) 'megtorpan, visszahököl', meccsólkollya (Alsócsitár) 'megcsókolja', mëllaktam (Kolon) 'beeszik', jóllakik', mërroskadt (Mátraalja), mëttanáta (Somoskőújfalu), mëzzabát (Besenyőtelek) '<ember mértéktelen evéstől, ivástól> megcsömörlik'; mëzzsäró 'megzsarol'. Az Ipoly menti palóc tájszótár is sok hasonló adatot közöl (vö. TóTH 1987: 183-190) stb.

E kérdéskörrel kapcsolatban ezek után azt lenne érdemes bemutatni, hogy a régió mely településein általánosabb a teljes hasonulás. Az adatokat térképen ábrázolva megállapíthatnánk - a nagyatlasszal összevetve - e fontos nyelvjárási sajátosság jelenséghatárait.

\section{7. táblázat}

A meg igekötő teljes hasonulása

\begin{tabular}{|l|l|l|l|l|l|l|}
\hline \multirow{2}{*}{ Címszó } & \multicolumn{3}{|c|}{ MNyA. } & \multicolumn{3}{c|}{ MedvA. } \\
\cline { 2 - 7 } & hasonul & nem hasonul & összes & hasonul & nem hasonul & összes \\
\hline meghív & 1 & 5 & 6 & 4 & 10 & 14 \\
\hline megnézzük & 6 & 4 & 10 & 6 & 6 & 12 \\
\hline megnő & 7 & 7 & 14 & 9 & 10 & 19 \\
\hline megver & 6 & 4 & 10 & 12 & 4 & 16 \\
\hline kifakad & 3 & 2 & 5 & 1 & 5 & 6 \\
\hline \multirow{2}{*}{ összes } & 23 & 22 & 45 & 32 & 35 & 67 \\
& $51,11 \%$ & $48,89 \%$ & $100 \%$ & $47,76 \%$ & $52,23 \%$ & $100 \%$ \\
\hline
\end{tabular}

Bár a hasonulásos változatok gyüjtésünk idején is jellemzők voltak, csökkent az előfordulásuk.

2.1.4. A -val/-vel rag $v$-je területünkön ma már hasonult formában is előfordul: késvel késsel, a lábbal térképén pedig lābvàl $(1-5,7,10,12$.) lābbàl $(2-3,6,8,9,11)[\underline{4}$. melléklet: MedvA. 541.]. Adataim alapján kijelenthetjük, hogy IMRE SAMU kizárólagos megállapítása korunkban nem érvényes (vö. IMRE 1971: 351), ugyanis ahogy a következő táblázatból kiderül, az adatok több mint ötöde már hasonult formában használatos. 
Élő nyelv

\section{8. táblázat}

A -val/-vel rag teljes hasonulása

\begin{tabular}{|l|l|l|l|l|l|l|}
\hline \multirow{2}{*}{ Címszó } & \multicolumn{3}{|c|}{ MNyA. } & \multicolumn{3}{c|}{ MedvA. } \\
\cline { 2 - 7 } & hasonul & nem hasonul & összes & hasonul & nem hasonul & összes \\
\hline késsel & 1 & 7 & 8 & 1 & 12 & 13 \\
\hline lábbal & 2 & 6 & 8 & 6 & 8 & 14 \\
\hline kézzel & 2 & 9 & 11 & 3 & 12 & 15 \\
\hline \multirow{2}{*}{ összes } & 5 & 22 & 27 & 10 & 32 & 42 \\
& $18,52 \%$ & $81,48 \%$ & $100 \%$ & $23,81 \%$ & $76,19 \%$ & $100 \%$ \\
\hline
\end{tabular}

2.1.5. Ma is általános, hogy pótlónyúlással kiesik az $l$ az -ol-, -öl- hangkapcsolatokban (vö. IMRE 1971: 350): nyolc nyóc, gyümölcs gyümöcs, szemöldök szemödök stb. Ehhez hasonló, de pótlónyúlás nélküli jelenség tapasztalható a bajusza (gabonáé) címszó adataiban (MedvA. 9.) is: $s z \bar{a} k \dot{a}$, de még általánosabban a szálka realizációiban: $s z \bar{a} k \dot{a}$. Az $l$ más hangkapcsolatokban, sőt szó végén is kieshet. A szótagzáró $l$ nélküli forma áll szemben az l-essel: szívà $\sim$ szilvá (MedvA. 87.). Szóvégen is megtörténhet az $l$ kiesése: (MedvA. 222. kanál) kànā, (MedvA. 389. köpül) köpü küpü. Megjegyzendö, hogy a nagyatlasz adott pontjain is hasonló adatok találhatók, sőt a kanál esetében káná is (H-6, Cssz-17). Az $l$ itt bemutatott kiesése a mai nyelvhasználatban is erős ugyan, de a számadatok szerint kis mértékben gyengült.

9. táblázat

Az -l- kiesése

\begin{tabular}{|l|l|l|l|l|l|l|}
\hline \multirow{2}{*}{ Címszó } & \multicolumn{3}{|c|}{ MNyA. } & \multicolumn{3}{c|}{ MedvA. } \\
\cline { 2 - 7 } & $-l-$ & $-0-$ & összes & $-l-$ & $-0-$ & összes \\
\hline szálka & 2 & 8 & 10 & 8 & 6 & 14 \\
\hline nyolc & - & 6 & 6 & - & 15 & 15 \\
\hline szilva & 4 & 2 & 6 & 10 & 5 & 15 \\
\hline kanál & 2 & 2 & 4 & 9 & 10 & 19 \\
\hline köpül & 4 & 2 & 6 & 9 & 6 & 15 \\
\hline \multirow{2}{*}{ összes } & 12 & 20 & 32 & 36 & 42 & 78 \\
& $37,5 \%$ & $62,5 \%$ & $100 \%$ & $46,15 \%$ & $53,85 \%$ & $100 \%$ \\
\hline
\end{tabular}

\subsection{Alaktan}

\subsubsection{A névszótövek}

2.2.1.1. „Az $O \dot{O} \sim a, \overparen{O} \sim e$ váltóhangot mutató tövek nyelvjárásainkban gyakoribbak, mint a köznyelvben. E gyakoriság földrajzi aspektusa azonban egyelőre nem nagyon körvonalazható" - írja IMRE SAMU (1971: 303). Bár teljes biztonsággal körvonalazni én sem tudom ezt a jelenséget, de néhány adalékkal bővíthetem eddigi ismereteinket. Az $o ́ \sim a$ váltakozás a disznó : disznaja alakpár esetében sokkal ritkább keleten, mint nyugaton, $\mathrm{s}$ elsősorban az északi területeken fordul elö a diszna- tő (vö. IMRE 1971: 303). Medvesalji adataim (MedvA. 329.) ezt csak részben igazolják, ugyanis ma a disznója (1-3, 5-10, 12) az uralkodó, s a disznájà (2-4, 10-11) már visszaszorulóban van, vagyis változás mutatható ki e tőváltozat használatában. 
A csípője (MNyA. 516.) morfológiai címszóhoz tartozó adatok között Medvesalján egy kutatóponton fordul elö csípeje csípeji, a csípője az általánosabb, s több helyen a tomporá járja. Az atlaszban a H-7. és 10. pontról nincs adat, a Cssz-17-en csípője („újabb” minősítéssel), a H-6. és a Cssz-18, 19. pontokon pedig csípeje. A csípeje változatot a RagSz. ritkább használatúnak tartja (vö. ELEKFI 1994: 135). Az erdeje (MNyA. 991.) realizációja Medvesalján föként erdejë és erdeji, s csupán egy helyen erdőjë, egy másikon pedig erdőji. (MedvA. 734.) Az atlaszban a H-6. és a Cssz-17-18. pontokon egymás mellett található az erdeje erdeji és az erdöjë erdőji adat, s csak a Cssz-19-esen áll önmagában az erdejë. Az mindenképpen kiderül, hogy ma is használják az ö-s alakot, de kisebb körben, mint az atlasz gyüjtése korában. „Ez a tőcsoport hajlik az egyalakúságra” - állapítja meg a MMNy. címü tankönyv (RÁCz 1971: 108). A medvesalji adatok az erdeje esetében azt mutatják, hogy itt az egyalakúság felé vezető úton még kevésbé indult el ez a tőtípus. Az egyalakúsodást azonban keresztezheti a mezője és mezeje, a tetője és teteje, a tüdője és tüdeje stb. alakpárok köznyelvben mutatkozó jelentésbeli elkülönülése.

10. táblázat

Az ó/ö a/e tôváltozat

\begin{tabular}{|l|l|l|l|l|l|l|}
\hline \multirow{2}{*}{ Címszó } & \multicolumn{3}{|c|}{ MNyA. } & \multicolumn{3}{c|}{ MedvA. } \\
\cline { 2 - 7 } & $-\dot{o}-,-, o ̈-$ & $-a-,-e-$ & összes & $-o ́-,-o ̈-$ & $-a-,-e-$ & összes \\
\hline disznó & 3 & - & 3 & 10 & 5 & 15 \\
\hline csípö* & 1 & 5 & 6 & 9 & 3 & 12 \\
\hline erdő & 5 & 9 & 14 & 3 & 11 & 14 \\
\hline \multirow{2}{*}{ összes } & 9 & 14 & 23 & 22 & 19 & 41 \\
& $39,13 \%$ & $60,87 \%$ & $100 \%$ & $53,66 \%$ & $46,34 \%$ & $100 \%$ \\
\hline
\end{tabular}

* Nincs a MedvA.-ban.

2.2.1.2. A v-s változatú névszótövek viselkedése sokrétübb a nyelvjárásokban, mint a köznyelvben (vö. IMRE 1971: 304-305). A morfológiai célzatú címszók közül a faluk (MNyA. 982., MedvA. 733.), a tetük (MNyA. 979., MedvA. 628.), a tetves (MNyA. 980.) és a füves (MNyA. 83., MedvA. 23.) adatait tanulságos bemutatni.

Medvesalján föváltozat a fảluk, mellékváltozat a köznyelvi fàlvák. A kiválasztott atlaszpontokon egyöntetüen fàluk (H-6, 7, 10, Cssz-17-19) található.

A nyelvatlaszban egységesen tetyük (H-6, 7, 10, Cssz-17-19) adatokat jegyeztek föl. Gyüjtésemben (MedvA. 628.) a tetyük tetük alak a domináns, a tetyvek pedig másodrendü. A tetü $-s$ képzős származékában a $v$-s tövü változat, a tetves $\sim$ tetyves az uralkodó gyüjtési területemen is, a nagyatlaszban is (H-7, 10, Cssz-17-19). Csupán a H-6. ponton fordul elő tetyüs alak, de az is „ritka” minősítéssel.

11. táblázat

A v-s tövek

\begin{tabular}{|l|l|l|l|l|l|l|}
\hline \multirow{2}{*}{ Címszó } & \multicolumn{3}{|c|}{ MNyA. } & \multicolumn{3}{c|}{ MedvA. } \\
\cline { 2 - 7 } & \multicolumn{1}{|c|}{$v$-s tő } & szótári tő & összes & $v$-s tő & szótári tő & összes \\
\hline faluk & - & 6 & 6 & 4 & 10 & 14 \\
\hline tetük & - & 6 & 6 & 3 & 10 & 13 \\
\hline tetves & 8 & 1 & 9 & 13 & 1 & 14 \\
\hline \multirow{2}{*}{ összes } & 8 & 13 & 21 & 20 & 21 & 41 \\
& $38,1 \%$ & $61,9 \%$ & $100 \%$ & $48,8 \%$ & $51,2 \%$ & $100 \%$ \\
\hline
\end{tabular}

* Nincs a MedvA.-ban. 
A fenti adatok azt mutatják, hogy a köznyelvi változat irányába történt elmozdulás. „Főképpen a palóc területekre jellemző [...] a fü : füves megoldás” - állapítja meg IMRE SAMU (1971: 305). A kiválasztott atlaszpontok mindegyikén fưves található, Medvesalján azonban a füves (9 kutatóponton) mellett a köznyelvi füves (3 kutatóponton) is feltünik.

(Folytatjuk.)

\section{1. sz. melléklet}

\section{Kutatópont-hálózat}

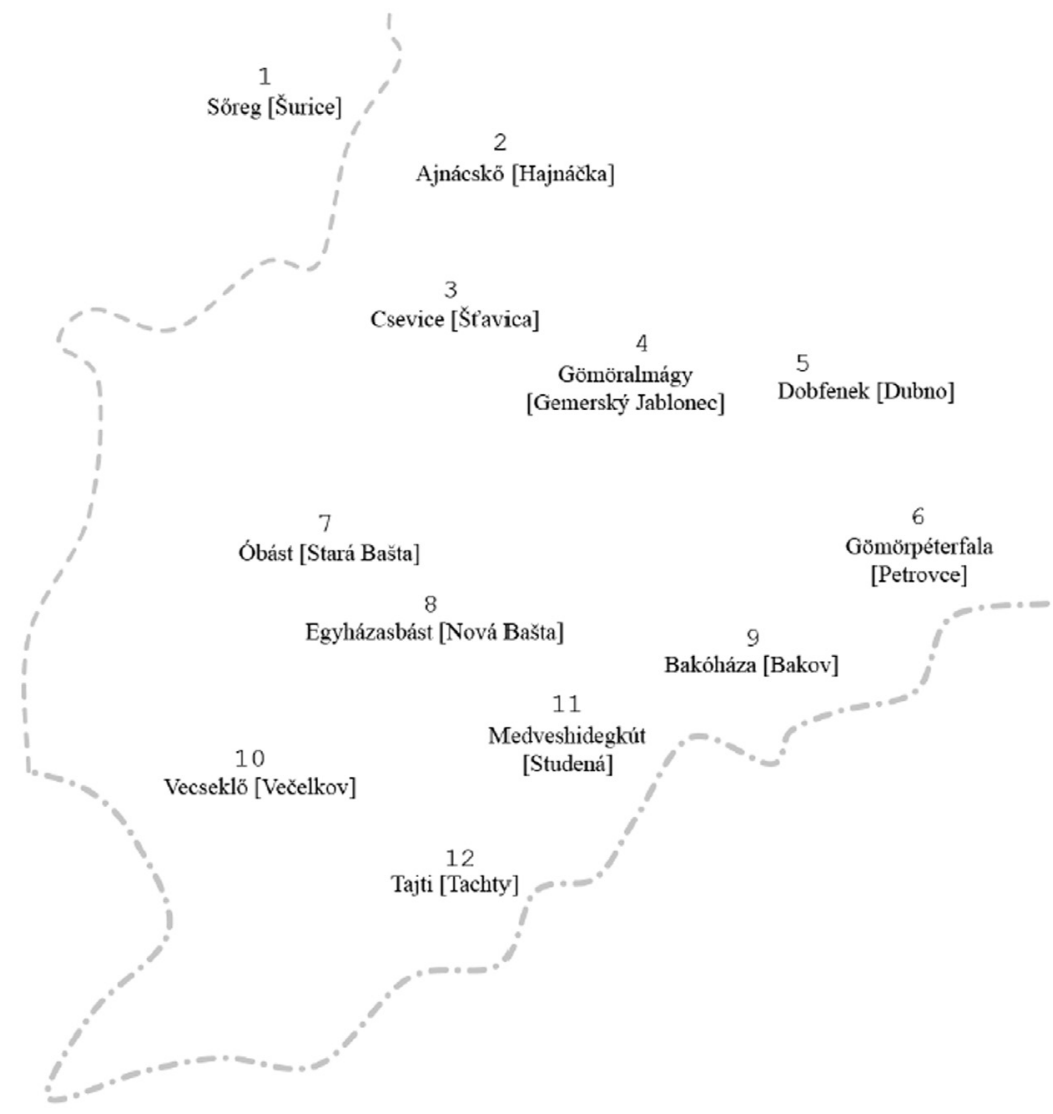

CS. NAGY LaJos

Comenius Egyetem, Pozsony 